\title{
Comparison between Siderophores Production by Fungi Isolated from Heavy Metals Polluted and Rhizosphere Soils
}

\author{
Khalid A. Hussein and Jin Ho Joo*
}

\begin{abstract}
Department of Biological Environment, Kangwon National University, Chuncheon, Kangwon-do, Republic of Korea
\end{abstract}
\begin{abstract}
Although siderophores are induced primarily in response to iron deficiency, soil and other ecological factors can affect on this process. This study was to evaluate the production of siderophores by different fungal species isolated from heavy metal contaminated and uncontaminated soils. More than thirty fungal strains were isolated from heavy metal contaminated and rhizosphere uncontaminated soils. Chrome azurol sulfonate (CAS) was used for both quantitative and qualitative evaluation of siderophores production. No significant correlations were observed between the tested variables such as ultraviolet (UV) irradiation method and CAS-agar plate and heavy metal concentration in both soils. The production of siderophores in rhizosphere fungi was higher than those isolated from the contaminated soil; however, the difference was not significant. The siderophore production (\%) by fungi isolated from heavy metal contaminated soil using UV irradiation method was positively correlated with the qualitative values using $C A S-p l a t e$ method $(P<0.05)$. Pearson comelation test indicated a positive correlation between the quantitative and qualitative methods of detection for fungi isolated from rhizosphere and also those isolated from heavy metal contaminated soil.
\end{abstract}

Key words: Siderophore, Heavy metal, Fungi, Rhizosphere soil, Chrome azurol sulfonate

\section{Introduction}

Although iron is one of the most common elements in nature, it is not readily available to microorganisms because of its extreme insolubility in aerobic conditions of water and soil environments. Therefore, most of the microorganisms produce high-affinity ferric chelating compounds with low molecular mass $(<1,000 \mathrm{Da})$ termed siderophores, which solubilize and transport the metal (Neilands, 1981). Siderophores excretion is one of the important features of plant growth promoting rhizobacteria (PGPR) in their ability to suppress soil-borne plant pathogens (McCully, 2005). Indeed, the binding affinity of plant siderophores for iron is less than the affinity of microbial siderophores, but plants require a lower iron concentration for normal growth than do microbes (Meyer, 2000). Evidence has been shown that the chemical conditions of the rhizosphere differ from those of the bulk soil, as a consequence of various processes that are induced by plant roots and/or by the microorganisms (Hinsinger, 2001). Actually, the root exudates act as

\footnotetext{
Received : 2012. 8. 17 Accepted : 2012. 9. 10

*Corresponding author : Phone: +82332506448

E-mail: jhjoo@kangwon.ac.kr
}

messengers that stimulate the interaction between the plants roots and soil microorganisms. Therefore, the environmental factors including soil characteristics or the soil composition are very important to affect the activity of microorganisms (Bent et al., 2001). High levels of heavy metals could decrease the rhizosphere microbial metabolic activity, biomass and diversity (Gremion et al., 2004; Sandaa et al., 1999). Kanazawa et al. (1994) recognized that plants grown in metal-contaminated soils are often iron deficient. Also, it was concluded that high levels of heavy metals could affect both structure of microbial communities and metabolic activity (Gremion et al., 2004; Kozdro and Van-Elsas 2001). However, it was found that zinc increased the production of a green fluorescent pigment (Bhattacharya, 2010; Shinozaki et al., 2004). Also, $\mathrm{Zn}^{2+}$ and $\mathrm{Cu}^{2+}$ increase fluorescent siderophore production (Dimpka et al., 2012). $\mathrm{Cu}^{2+}$ or $\mathrm{Ni}^{2+}$ was also found to promote the production of a yellow pigment in P. fluorescens-putida (Chakrabarty and Roy, 1964). Dell'Amico et al. (2005) found a large number of metal resistant strains, which were able to produce siderophores. The objective of this study was to evaluate the production of siderophores by different fungi isolated from heavy metal contaminated and uncontaminated soils. In addition, 
Table 1. Physicochemical and biological properties of the soils.

\begin{tabular}{|c|c|c|c|c|c|c|c|c|c|c|c|c|c|}
\hline \multirow{2}{*}{ Soil } & \multirow{2}{*}{$\mathrm{pH}$} & \multirow{2}{*}{$\mathrm{EC}$} & \multirow{2}{*}{$\mathrm{NH}_{4}-\mathrm{N}$} & \multirow{2}{*}{$\mathrm{NO}_{3}-\mathrm{N}$} & \multicolumn{2}{|c|}{ Exch. cation $^{\dagger}$} & \multirow{2}{*}{$\begin{array}{l}\text { Bacteri Fungi } \\
-\left(\times 10^{4}\right) \quad\left(\times 10^{4}\right)\end{array}$} & \multicolumn{6}{|c|}{ Heavy metal contents } \\
\hline & & & & & $\mathrm{Ca}^{2+} \mathrm{Mg}^{2+}$ & $\mathrm{K}^{+} \mathrm{Na}^{+}$ & & $\mathrm{Cd}$ & $\mathrm{Cr} \quad \mathrm{Ni}$ & $\mathrm{Cu}$ & $\mathrm{Zu}$ & Co & $\mathrm{Fe}$ \\
\hline & $(1: 5)$ & $\mathrm{dS} \mathrm{m}^{-1}$ & -- mg & $\mathrm{kg}^{-1}--$ & --- $\mathrm{cmol}_{\mathrm{c}}$ & $\mathrm{kg}^{-1}---$ & -CFU g ${ }^{-1}$ soil- & - & -------- m & $\mathrm{g} \mathrm{kg}^{-1}$ & $-\cdots$ & -- & -------- \\
\hline $\begin{array}{c}\mathrm{Hm} \\
\text { contaminated }\end{array}$ & 6.1 & 0.1 & 7.2 & 1.7 & $14.2 \quad 4.5$ & $\begin{array}{lll}0.6 & 0.1\end{array}$ & 45.0 & 3.91230 .7 & 10.25 .1 & 105.1 & 529.5 & 4.7 & 17714.6 \\
\hline Uncontaminated & 6.7 & 0.1 & 3.0 & 7.1 & $10.9 \quad 1.2$ & 0.40 .3 & $2100.0 \quad 70.0$ & $1.7 \quad 42.0$ & $8.8 \quad 4.4$ & 14.0 & 104.8 & 2.5 & 11926.3 \\
\hline
\end{tabular}

the correlation between values detected from the qualitative and quantitative methods was determined.

\section{Materials and methods}

Microorganisms and growth conditions Fungal strains were isolated from two different soil origins: 1) soil polluted with heavy metals from mining area "Bongwha county, Kyungsang province". 2) The rhizosphere of Pinus koraiensis shrubs in the forest area at Chuncheon, 192-1 Hyo-Ja Dong, Kangwon-do 200-701, South Korea. Soil samples were collected in clean zipper bags and ice box and directly transferred to laboratory for physicochemical properties detection. Several fungi belonging to different classes were used in this study (Table 1). Stock cultures of fungi were maintained on $2 \%$ malt extract-agar (MEA) plates grown at $27^{\circ} \mathrm{C}$ and stored at $4{ }^{\circ} \mathrm{C}$.

Soils physical and chemical properties The soil $\mathrm{pH}$ and electric conductivity EC of soil and water mixtures (1:5) were determined using a $\mathrm{pH}$ meter (Orion $3 \mathrm{Star}$, Thermo, USA). The exchangeable cations were analyzed by inductively coupled plasma (ICP) spectrometry after 1 $\mathrm{M} \mathrm{NH}_{4} \mathrm{OAc}$ extraction (Sumner and Miller, 1996). Soil samples were air-dried and shaken through a 2-mm sieve. The total concentration of heavy metals was estimated by digestion in $10-\mathrm{mL} 60 \% \mathrm{HNO}_{3}$ and microwave oven-drying at $200 \pm 5^{\circ} \mathrm{C}$ for $20 \mathrm{~min}$ (Mars-X, HP-500 plus, CEM Corp.) according to EPA Method 3051 (USEPA, 1994). The concentrations of $\mathrm{Co}, \mathrm{Cr}, \mathrm{Cu}, \mathrm{Fe}, \mathrm{Ni}, \mathrm{Pb}$, and $\mathrm{Zn}$ were determined by inductively coupled plasma/atomic emission spectroscopy (ICP-AES; Perkin Elmer Optima, USA).

Identification of isolates Several methods were used for identification of microorganisms. Most of fungal strains were identified by the microscopic examination and the culture features according to Domsch et al. (1980) and Moubasher (1993). In addition, molecular techniques were applied for quick and accurate identification of some fungal strains. The genomic DNA was isolated from fungi according to the manufacturer's instructions using a genomic DNA Prep Kit (SolGent, Daejeon, Korea). The isolated DNA was then used as a template for PCR to amplify the 18S rRNA gene. The partial 18S rRNA gene sequence was compared with the full sequence available in the GenBank database using a BLAST search (NCBI) to identify the isolated fungi.

Qualitative detection of siderophore (Plate assay)

To avoid the toxic effect of the chrome azurol sulfonate (CAS) to fungi, modified method, CAS agar half plate assay, was used for the siderophores detection. For the CAS agar half in the plates, before autoclaving the CAS agar, $\mathrm{pH}$ was raised to 6.8 using $\mathrm{NaOH}$ solution $50 \%$ $(\mathrm{w} / \mathrm{v})$. CAS agar half plate assay was performed according to Milagres et al. (1999) using MEA media pH 5.6 for qualitative detection of fungi production. The isolates were subcultured on MEA slants and incubated at $27^{\circ} \mathrm{C}$. After 5 days culture, spores were scratched into $5 \mathrm{~mL}$ of distilled sterile water containing $1 \%$ Tween 80 and were vortexed, and using cell-counting haemocytometer (Neubauer chamber; Merck S.A., Madrid, Spain). The suspensions were adjusted to $1.0 \times 10^{6} \mathrm{cfu} \mathrm{mL}^{-1}$. The length of the change in the blue color indicates the siderophores activity. Incubation period was until the fungal colony grew across the MEA medium half of the plate or maximally 15 days (Fig. 1).

\section{Quantitative spectrophotometric assay for siderophore} production (Liquid assay) CAS liquid assay was used according to Schwyn and Neilands (1987). The $\mathrm{pH}$ was adjusted to pH 6.8 with 0.1 M Pipes buffer (Sigma, Prod. 

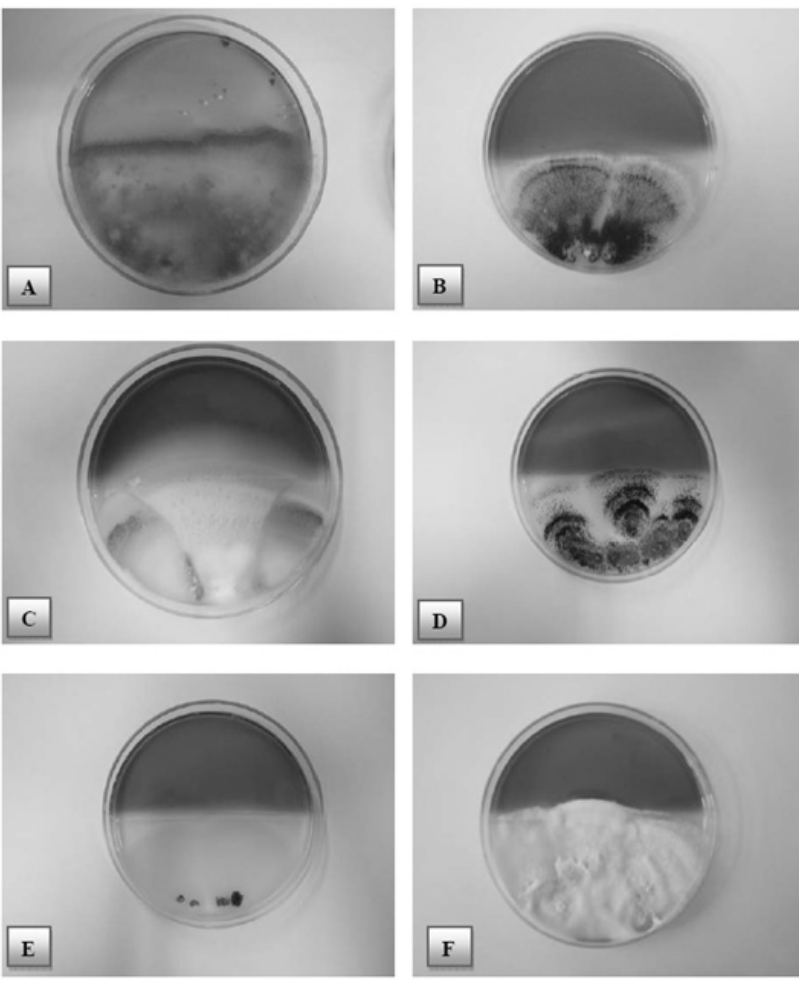

Fig. 1. The CAS-agar half plate as qualitative method for detection of sidemophores excretion by Botrytis aclada (A), Metarhizium anisopliae (B), Penicillium chrysogenum (C), Aspergillus niger (D), Cladosporium sp (E), and Beauveria bassiana (F).

No. P1851). The cultures were grown to stationary phase in the deferrated media. $0.5 \mathrm{~mL}$ CAS assay solution was added to $0.5 \mathrm{ml}$ culture supernatant and $10 \mu \mathrm{L}$ of $0.2 \mathrm{M}$ 5 -sulfosalicylic acid as shuttle solution and mix. The mixtures were left for few minutes. Siderophores, if present, withdrew iron from the dye complex, resulting in a reduction in blue color of the solution. The color development was measured by absorbance $\left(\mathrm{A}_{630}\right)$ for loss of blue color. The sterile culture medium was used as blank and the sterile culture medium plus CAS and shuttle solutions were used as a reference. Siderophores units were calculated as $[(A r-A s) / A r] 100=\%$ siderophores units; where $A r$ is the absorbance reading of the reference, and $A s$ is the absorbance reading of the sample.

Statistical analysis The means of the variables were compared using Tukey's HSD test at a probability level of $(\mathrm{P})<0.05$ (SAS Institute Inc, 2004). In addition, Pearson correlation coefficients between heavy metal concentration in the soil and siderophores production were calculated. Similarly correlation between ultraviolet (UV) irradiation detection and the qualitative detections was estimated.

\section{Results and Discussion}

The specificity of microorganism's metabolic character is dependent upon soil conditions, which can alter contaminant bioavailability, root exudates composition, and nutrient levels (Jing et al., 2007). The physicochemical properties of the studied soils are described in Table 1. The microbial count of bacteria and fungi in the contaminated soil was very lower compared to the rhizosphere. Table 1 shows that bacterial counts were $2 \times$ $10^{4} \mathrm{CFU} \mathrm{g}^{-1}$ in soil and $2,100 \times 10^{4} \mathrm{CFU} \mathrm{g}^{-1}$ in heavy metal contaminated soil and rhizosphere soils, respectively. Heavy metals can cause reproduction of soil microorganisms to slow down and consequently prevail higher resistance to heavy metals, but decreased biological activity (Šimon, 1999). The metal resistant siderophores producing bacteria plays an important role in the successful survival and growth of plants in contaminated soils by alleviating the metal toxicity and supplying the plant with nutrients, particularly iron (Rajkumar and Freitas, 2009). On the other hand, rhizosphere microorganisms compete for nutrients and space (Elad and Baker, 1985; Elad and Chet, 1987) and production of siderophores (fluorescent yellow green pigment), viz., pyoverdine which limits the availability of iron necessary for the growth of pathogens (Lemanceau et al., 1992). Here we evaluated the production of siderophores by different fungi species isolated from heavy metal contaminated soil compared rhizosphere soils. Our qualitative detections were carried out in parallel with the UV spectroscopy quantitative method for cross confirmation and to make a correlation between them. Generally, fungi are stronger siderophores producers than bacteria. Most fungi produce a variety of different siderophores, which enable them to adapt different physicochemical conditions (Winkelmann, 2007). Furthermore, fungi can uptake the bacterial siderophores. Haas (2003) stated that certain fungi can utilize ferrioxamines and enterobactin. Also, the feeding ecology of fungi greatly differs from that of bacteria (Winkelmann, 2007). Fungi of contaminated soil produced siderophores at highest level of $92.75 \%$ by Acremonium sp. and the lowest production was $7.24 \%$ by Saccharomyces sp. According to our results the rhizosphere fungi, Penicillium sp., Trichoderma sp. and Beauveria bassiana, showed frequency of high production $90.89 \%, 92.33 \%$, and $89.44 \%$, respectively. However, Rhodosporidium toruloides produced the lowest units (6.41\%) of siderophores (Table 2). 
Table 2. Quantitative spectrophotometric assay for siderophore production by fungal species isolated heavy metal contaminated and rhizospheric soils.

\begin{tabular}{|c|c|c|c|c|}
\hline$\overline{\text { Species }}$ & Affinity & $\begin{array}{l}\text { Absor- } \\
\text { ancw at } \\
530 \mathrm{~nm}\end{array}$ & Reference & $\begin{array}{c}\% \text { Sider- } \\
\text { phores }\end{array}$ \\
\hline \multicolumn{5}{|l|}{ Rhizospheric soil } \\
\hline Penicillium digitatum & Ascomycetes & 0.167 & 0.483 & 84.26 \\
\hline Botrytis sp. & Deuteromycetes & 0.097 & 0.483 & 79.91 \\
\hline Penicillum sp. & Ascomycetes & 0.119 & 0.483 & 75.36 \\
\hline Penicillium chrisogenum & Ascomycetes & 0.044 & 0.483 & 90.89 \\
\hline Aspergillus niger & Ascomycetes & 0.058 & 0.483 & 87.99 \\
\hline Mucor sp. & Zygomycetes & 0.068 & 0.483 & 85.92 \\
\hline Beauveria bassiana & Deuteromycetes & 0.123 & 0.483 & 89.44 \\
\hline Saccharomyces sp. & Ascomycetes & 0.051 & 0.483 & 74.53 \\
\hline Metarhizium anisopliae & Deuteromycetes & 0.068 & 0.483 & 85.92 \\
\hline Trichoderma harizianum & Deuteromycetes & 0.037 & 0.483 & 92.33 \\
\hline Fusarium sp. & Deuteromycetes & 0.098 & 0.483 & 79.71 \\
\hline Fusarium oxysporum & Deuteromycetes & 0.069 & 0.483 & 85.71 \\
\hline Rhodosporidium toruloides & Basidiomycetes & 0.452 & 0.483 & 6.41 \\
\hline Cladosporium sp. & Deuteromycetes & 0.205 & 0.483 & 57.55 \\
\hline Alternaria sp. & Deuteromycetes & 0.217 & 0.483 & 55.07 \\
\hline Penicillium requeforti & Ascomycetes & 0.081 & 0.483 & 83.22 \\
\hline \multicolumn{5}{|c|}{ Heavy metal contaminated soil } \\
\hline Botrytis aclada & Deuteromycetes & 0.295 & 0.483 & 38.92 \\
\hline Penicillium notatum & Ascomycetes & 0.109 & 0.483 & 77.43 \\
\hline Aspergillus flavus & Ascomycetes & 0.246 & 0.483 & 49.06 \\
\hline Aspergillus flavus & Ascomycetes & 0.264 & 0.483 & 45.34 \\
\hline Saccharomyces sp. & Ascomycetes & 0.448 & 0.483 & 7.24 \\
\hline Sacharomyces sp. & Ascomycetes & 0.117 & 0.483 & 75.77 \\
\hline Penicillium verrucosum & Ascomycetes & 0.266 & 0.483 & 44.92 \\
\hline Aspergillus niger & Ascomycetes & 0.079 & 0.483 & 83.64 \\
\hline Acremonium sp. & Ascomycetes & 0.035 & 0.483 & 92.75 \\
\hline Rhodotorula sp. & Basidiomycetes & 0.061 & 0.483 & 87.37 \\
\hline Bipolaris sp. & Deuteromycetes & 0.108 & 0.483 & 77.63 \\
\hline Cladosporium $\mathrm{sp}$ & Deuteromycetes & 0.1 & 0.483 & 79.29 \\
\hline Penicillium glabrum & Ascomycetes & 0.177 & 0.483 & 63.53 \\
\hline Morterilla sp. & Zygomycetes & 0.41 & 0.483 & 15.11 \\
\hline Trichoderma sp. & Deuteromycetes & 0.17 & 0.483 & 64.8 \\
\hline Epicoccum sp. & Deuteromycetes & 0.247 & 0.483 & 48.68 \\
\hline
\end{tabular}

Although the microbial ecology in the rhizosphere is not yet fully understood, the plant exudates enrich the metabolic activity of the present microflora, moreover, rhizobacteria have been shown to possess several traits that can alter heavy metals bioavailability (Lasat, 2002). Our results, generally, indicated that siderophores production was not significantly different between heavy metal soil and rhizosphere soil; however, there was a trend for higher siderophore production in rhizosphere than heavy metal soil. The rhizosphere area contains microbial population with higher metabolic activity rather than bulk soil (Anderson et al., 1993). However, microbial populations can affect heavy metals mobility and availability to the plant through release of chelating agents, acidification, phosphate solubilization, and redox changes (Abou-Shanab et al. 2003). According to our results no significant correlations were observed between the tested variables and heavy metal concentration in both soils (data not shown). This may indicate that the production of siderophores is depended on other soil chemical and biological properties rather than heavy metal concentrations present in its original environment. Also, these specific microorganisms could be tolerated or adapted with heavy metals concentration in the contaminated soil. Hofte et al. (1994) suggested that the heavy metal might be directly involved in siderophore biosynthesis pathways or their regulation. Also, Dimkpa et al. (2008) assumed that the free siderophore concentration in the medium might be reduced by complex formation with heavy metal ions. This process interferes with the complexation of siderophores with iron which consequently decreases the soluble iron concentration. As iron deficiency stimulates siderophore production, more siderophores would then be produced. Although, iron is abundant, it is not easily available and therefore investigation of other ecological factors is necessary to understand the iron mobilization in nature. There was no significant difference in the production of siderophores by the commensals and isolates from clinical samples. Therefore they expected that any bacteria would produce sufficient quantities of siderophore when grown in an iron deficient environment and incubated at its optimum growth conditions (Pal and Gokarn, 2010). In the qualitative assay of fungi the clearest detection was observed among Penicillium spp. and Aspergillus niger (Table 3). It is well known that, ferrichrome are the predominant siderophores of Aspergillus and Penicillium strains. Trichoderma, Botrytis, and soil yeasts utilize ferrichromes. Pseudomonads are characterized by pyoverdines secretion (Winkelmann, 2007).

As shown in Table 4, the siderophore production (\%) by fungi isolated from heavy metal contaminated soil using UV irradiation method was positively correlated with the qualitative values using CAS-plate method $(P<0.05)$ (Table 4). In rhizosphere soil, the siderophore producing fungi using UV irradiation method was significantly correlated with the qualitative values CAS-agar plate $(P<$ 0.01 ). In general, the siderophore production of rhizosphere microorganisms is higher than those isolated from contaminated soil; however, the difference was not significant (Fig. 2). The presence of fungi in the rhizosphere area is more stimulating siderophores production, rather than heavy metal polluted area. The average amount of siderophores produced by fungi isolated from rhizosphere soil was 1.2-fold higher than 
Table 3. CAS agar plate assay (half-plate method) for siderophore production by fungal species isolated heavy metal contaminated and rhizospheric soils.

\begin{tabular}{|c|c|c|c|c|c|}
\hline Species & Affinity & $\begin{array}{c}\text { Color } \\
\text { development }\end{array}$ & $\begin{array}{c}\text { Color change } \\
\text { after }\end{array}$ & $\begin{array}{c}\text { Detection after } \\
15 \text { days }\end{array}$ & CAS detection \\
\hline \multicolumn{6}{|l|}{ Rhizospheric soil } \\
\hline Penicillium digitatum & Ascomycetes & Pink & 8 days & 22 & +++ \\
\hline Botrytis sp. & Deuteromycetes & Pink & 4 days & 25 & +++ \\
\hline Penicillum sp. & Ascomycetes & Pink & 7 days & 11 & + \\
\hline Penicillium chrisogenum & Ascomycetes & Yellow & 5 days & 15 & + \\
\hline Aspergillus niger & Ascomycetes & Pink & 5 days & 45 & +++ \\
\hline Mucor sp. & Zygomycetes & Purple & 4 days & 40 & +++ \\
\hline Beauveria bassiana & Deuteromycetes & Pink & 8 days & 25 & ++ \\
\hline Saccharomyces sp. & Ascomycetes & Pink & 13 days & 3 & \pm \\
\hline Metarhizium anisopliae & Deuteromycetes & Purple & 10 days & 17 & ++ \\
\hline Trichoderma harizianum & Deuteromycetes & Pink & 6 days & 30 & ++ \\
\hline Fusarium sp. & Ascomycetes & Pink & 8 days & 16 & ++ \\
\hline Fusarium oxysporum & Deuteromycetes & Pink & 8 days & 7 & + \\
\hline Rhodosporidium toruloides & Basidiomycetes & Pink & 13 days & 3 & \pm \\
\hline Cladosporium sp. & Deuteromycetes & Pink & 13 days & 21 & \pm \\
\hline Alternaria sp. & Deuteromycetes & Pink & 11 days & 7 & + \\
\hline Penicillium requeforti & Ascomycetes & Yellow & 9 days & 21 & +++ \\
\hline Control medium & - & Blue & - & - & - \\
\hline \multicolumn{6}{|c|}{ Heavy metal contaminated soil } \\
\hline Botrvtis aclada & Deuteromycetes & Pink & 7 davs & 15 & ++ \\
\hline Penicillium notatum & Ascomycetes & Purple & 10 days & 9 & + \\
\hline Aspergillus flavus & Ascomycetes & Pink & 11 days & 15 & ++ \\
\hline Aspergillus flavus & Ascomycetes & Pink & 11 days & 5 & \pm \\
\hline Saccharomyces sp. & Ascomycetes & Yellow & 13 days & 3 & \pm \\
\hline Sacharomyces sp. & Ascomycetes & yellow & 13 days & 3 & \pm \\
\hline Penicillium verrucosum & Ascomycetes & yellow & 13 days & 5 & \pm \\
\hline Aspergillus niger & Ascomycetes & Pink & 5 days & 40 & +++ \\
\hline Acremonium sp & Ascomycetes & Pink & 7 days & 39 & +++ \\
\hline Rhodotorula sp & Basidiomycetes & Pink & 5 days & 28 & +++ \\
\hline Bipolaris sp & Deuteromycetes & purple & 13 days & 13 & + \\
\hline Penicillium funiculosum & Ascomycetes & purple & 7 days & 11 & + \\
\hline Saccharomces sp & Ascomycetes & yellow & 13 days & 0 & - \\
\hline Cladosporium sp & Deuteromycetes & purple & 7 days & 3 & $\overline{ \pm}$ \\
\hline Penicillium glabrum & Ascomycetes & purple & 10 days & 11 & + \\
\hline Morterilla $\mathrm{sp}$ & Zygomycetes & Pink & 10 days & 6 & + \\
\hline Trichoderma $\mathrm{sp}$ & Deuteromycetes & pink & 6 days & 13 & + \\
\hline Epicoccum & Ascomycetes & Pink & 13 days & 15 & + \\
\hline Control medium & - & blue & - & - & - \\
\hline
\end{tabular}

The measured $\mathrm{Fe}$ ions concentration in MEA was $0.6595 \mathrm{mg} \mathrm{kg}^{-1}$.

${ }^{\dagger}$ No color change; \pm detection very low or absent; + low detection; ++ moderate detection; +++ high detection.

Table 4. Comelation coefficient values between \%siderophores production using UV imadiation and the qualitative detection methods.

\begin{tabular}{|c|c|c|}
\hline & $\begin{array}{c}\text { Pearson correlation coefficients }(r) \\
\text { siderophores producion } \%\end{array}$ & $\begin{array}{c}\text { Qualitative method (mm) }{ }^{*} \text { Plate method } \\
\mathrm{mm}\end{array}$ \\
\hline \multicolumn{3}{|l|}{ Rhizosphere fungi } \\
\hline siderophores producion (\%) & $1.000 * * *$ & $0.604 * *$ \\
\hline Qualitative method (mm) & & $1.000 * * *$ \\
\hline \multicolumn{3}{|l|}{ (Plate/Disc method) } \\
\hline \multicolumn{3}{|l|}{ HM-fungi } \\
\hline siderophores production $(\%)$ & $1.000 * * *$ & $0.548 * *$ \\
\hline Qualitative method (mm) & & $1.000 * * *$ \\
\hline (Plate/Disc method) & & \\
\hline
\end{tabular}




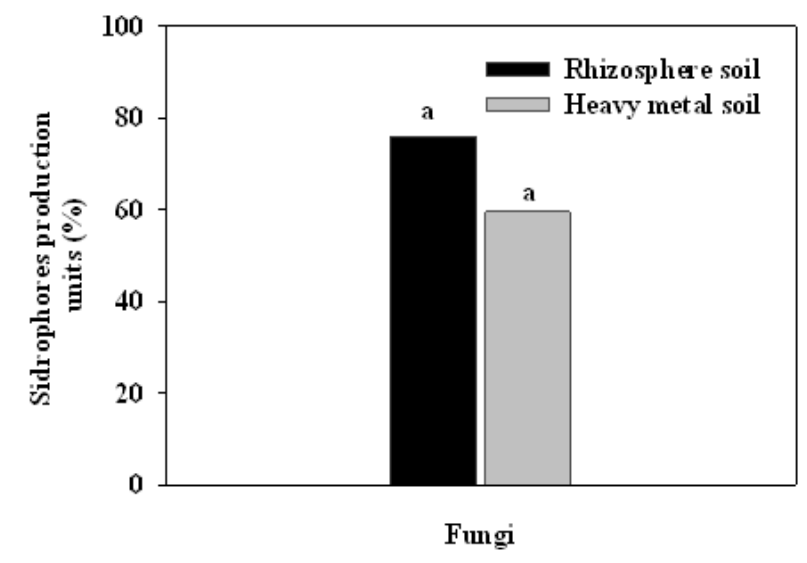

Fig. 2. Average of siderophores production by the isolated fungi in rhizosphere and heavy metal contaminated soils.

those in heavy metal contaminated soil.

\section{Acknowledgement}

This study was supported by National Research Foundation of Korea Grant funded by the Korean government (Project number: 2010-0011988)

\section{References}

Abou-Shanab, R.I., T.A. Delorme, J.S. Angle, R.L. Chaney, K. Ghanem, H. Moawad, and H.A. Ghozlan. 2003. Phenotypic characterizationofmicrobes in the rhizosphere of Alyssum murale. Int. J. Phytorem. 5:367-379.

Anderson, T.A., E.A. Guthrie, and B.T. Walton. 1993. Bioremediation. Environ. Sci. Technol. 27:2631-2636.

Bent, E., S. Tuzun, C.P. Chanway, and S. Enebak. 2001. Alterations in plant growth and in root hormone levels of lodgepole pines inoculated with rhizobacteria. Can. J. Microbiol. 47:793-800.

Bhattacharya, A. 2010. siderophore mediated metal uptake by pseudomonas fluorescens and its comparison to iron (iii) chelation Cey. J. Sci. (Bio. Sci.) 39:147-155.

Chakrabarty, A.M. and S.C. Roy. 1964. Nature of endogenous reserve material in a strain of Pseudomonas fluorescens-putida. Int. Biochem. J. 92:105-112.

Dell'Amico, E., L. Cavalca, and V. Andreoni. 2005. Analysis of rhizobacterial communities in perennial Graminaceae from polluted water meadow soil, and screening of metal-resistant, potentially plant growth-promoting bacteria. FEMS Microbiol. Ecol. 52:153-162.

Dimkpa, C.O., A. Svatoš, P. Dabrowska, A. Schmidt, W. Boland, and E. Kothe. 2008. Involvement of siderophores in the reduction of metal-induced inhibition of auxin synthesis in Streptomyces spp. Chemosphere 74:19-25.

Domsch, K.H., W. Gams, and T. Anderson. 1980. Compendium of soil fungi. Vols 1 and 2. Academic Press. London, 859-405.

Elad, Y. and R. Baker, 1985. The role of competition for iron and carbon in suppression of chlamydospore germination of Fusarium oxysporum. Phytopathology 75, 190-195.

Elad, Y. and I. Chet. 1987. Possible role of competition for nutrition in biocontrol of Pythium damping-off by bacteria. Phytopathology 77:190-195.

Gremion, F., A. Chatzinotas, K. Kaufmann, W. von Sigler, and H. Harms.2004. Impacts of heavy metal contamination and phytoremediation on a microbial community during a twelvemonth microcosm experiment. FEMS Microbiol. Ecol. 48: 273-283.

Haas, H. 2003. Molecular genetics of fungal siderophore biosynthesis and uptake: the role of siderophores in iron uptake and storage. Appl. Microbiol. Biotechnol. 62:316-330

Hinsinger, P. 2001. Bioavailability of soil inorganic P in the rhizospere as affected by root-induced chemical changes: a review. Plant Soil 237:173-195.

Hofte, M., Q. Dong, S. Kourambos, V. Krishnapillai, D. Sherratt, and M. Mergeay. 1994. The sss gene product, which affects pyoverdin production in Pseudomonas aeruginosa 7NSK2, is a site-specific recombinase. Mol. Microbiol. 14:1011-1020.

Jing, Y.D., Z.L. He, and X.E. Yang. 2007. Role of soil rhizobacteria in phytoremediation of heavy metal contaminated soils. J. Zhejiang Univ. Sci. B. 8:192-207.

Kanazawa, K., K. Higuchi, N.K. Nishizawa, S. Fushiya, M. Chino, and S. Mori. 1994. Nicotianamine aminotransferase activities are correlated to the phytosiderophore secretion under Fe-deficient conditions, in Gramineae. J. Exp. Bot. 45:1903-1906.

Pal, R.B. and K. Gokarn. 2010. Siderophores and pathogenecity of microorganisms. J. Biosci. Tech., 1:127-134.

Kozdro, J. and J.D. Van-Elsas. 2001. Structural diversity of microorganisms in chemically perturbed soil assessed by molecular and cytochemical approaches. J. Microbiol. Methods 43:197-212.

Lasat, H.A. 2002. Phytoextraction of toxic metals: a review of biological mechanisms. J. Environ. Qual. 31:109-120.

Lemanceau, P., P.A.H.M. Bakker, W.J. Dekogel, C. Alabouvette, and B. Schippers. 1992. Effect of pseudobactin 358 produced by Pseudomonas putida WSC358 on suppression of Fusarium wilt of carnations by non pathogenic Fusarium oxysporum. Appl. Environ. Microbiol. 58:2978-2980.

McCully, M. 2005. The rhizosphere: the key functional unit in plant/soil/microbial interactions in the field. Implications for the understanding of allelopathic effects. In Proceedings of the 4th World Congress on Allelopathy: 21-26 August 2005.

Meyer, J.M. 2000. Pyoverdines: pigments siderophores and potential taxonomic markers of fluorescent Pseudomonas species. Arch. Microbiol. 174:135-142.

Milagres, A.M.F., A. Machuca, and D. Napoleão. 1999. Detection of siderophore production from several fungi and bacteria by a modification of chrome azurol S (CAS) agar plate assay. J. Microbiol. Meth. 37:1-6.

Moubasher, A.H. 1993. Soil fungi in Qatar and other Arab countries. The Centre of Scientific and Applied Research, University of Qater, Doha, Qater.

Neilands, J.B. 1981. Microbial iron compounds. Ann.Rev.Biochem. 
50:715- 731 .

Rajkumar, M., and H. Freitas. 2009. Endophytic bacteria and their potential to enhance heavy metal phytoextraction. Chemosphere 77:153-60.

SAS Institute Inc, SAS, SAS/STAT ${ }^{\circledR} 9.1$ User's Guide. SAS Institute Inc., Cary, NC, USA, 2004.

Sandaa, R.A., V. Torsvik, O. Enger, L.F. Daae, T. Castberg, and D. Hahn. 1999. Analysis of bacterial communities in heavy metal-contaminated soils at different levels of resolution. FEMS Microbiol. Ecol. 30:237-251.

Schwyn, B. and J.B. Neilands. 1987. Universal chemical assay for the detection and determination of siderophores. Anal. Biochem. 160:47-56.

Shinozaki, Y., Y. Akutsu-Shigeno, T. Nakajima-Kambe, S. Inomata, N. Nomura, T. Nakahara, and H. Uchiyama. 2004.
Matrix Metalloproteinase-2 Inhibition and $\mathrm{Zn}^{2+}$ Chelating Activities of Pyoverdine-Type Siderophores J Biosci. Bioeng. 97:281-283.

Šimon, T. 1999. The effect of increasing rates of nickel and arsenic on the growth of radish and soil microflora. Rostlinna vyroba 45, 421-430. (in Czech).

Sumner, M.E. and W.P. Miller. 1996. Cation exchange capacity and exchange coefficients. p. 1201-1229. In D.L. Sparks (ed.) Methods of soil analysis. Part 3. SSSA Book Ser. 5. SSSA, Madison, WI.

U.S. Environmental Protection Agency (USEPA). 1994 Microwave assisted acid digestion of sediments, sludges, soils and oil. Method 3051.

Winkelmann, G. 2007. Ecology of siderophores with special reference to fungi. Biometals. 20:379-392. 